\title{
USO DE DENTIFRÍCIOS PELA POPULAÇÃO E A INFLUÊNCIA DA MÍDIA
}

Amanda Mahammad MUSHASHE, Joslei Carlos BOHN, Rodrigo RAZZOTO, Silvana de OLIVEIRA, Paulo Henrique TOMAZINHO

O objetivo deste trabalho foi avaliar o uso de dentifrícios pela população, assim como a influência da mídia na utilização e escolha dos cremes dentais. Foram realizadas duas pesquisas, sendo a primeira contemplando um grupo de 99 indivíduos e outra com 148. Os questionários aplicados foram de conteúdos distintos, sendo o primeiro com 10 perguntas, e o segundo 11. Na pesquisa I, foi encontrado que $85,81 \%$ da amostra utiliza uma quantidade inadequada de creme dental. Já na pesquisa II, 60,61\% complementa a escovação com algum tipo de colutório (descrito no questionário como anti-séptico). A influência da mídia foi constatada pela pesquisa II, verificando que os artifícios da publicidade determinam $48,48 \%$ das escolhas das pastas. Observou-se, portanto, que além da necessidade de uma maior acuidade quanto às informações fornecidas pelos comerciais, o campo odontológico deve-se apresentar mais ativo na educação da higiene oral.

Palavras-chave: Dentifrícios; Higiene bucal; Educação. 